УДК 669.053.4

\title{
ОБЗОР СОВРЕМЕННЫХ ТЕХНОЛОГИЙ ПЕРЕРАБОТКИ УПОРНЫХ ЗОЛОТОСОДЕРЖАЩИХ РУД И КОНЦЕНТРАТОВ С ПРИМЕНЕНИЕМ АЗОТНОЙ КИСЛОТЫ
}

\author{
Гордеев Даниил Валерьевич1, \\ danya.gordeev.2014@mail.ru
}

\author{
Петров Георгий Валентинович1, \\ petroffg@yandex.ru
}

\author{
Хасанов Артур Вячеславович 1 , \\ khasanov-a@gidrometall.ru
}

\author{
Северинова Ольга Валерьевна 1 , \\ argentumhelga@gmail.com \\ 1 Санкт-Петербургский Горный университет, \\ Россия, 199106, г. Санкт-Петербург, 21-я лин. В.О., 2.
}

\begin{abstract}
Актуальность. Упорность золотосодержащих руд обусловлена двумя фракторами: первый заключается в тонкой диспергации золота в сульфридных минералах, второй - в наличии углеродистого вещества, ответственного за протекание процесса прегроббинга, приводящего к неизбежному снижению извлечения золота. В современной золотоизвлекательной промышленности существует множество способов переработки упорного золота с содержанием углеродистого вещества до 1\%, однако более высокие его концентрации до сих пор вызывают большие проблемы. Одним из наиболее интересных и перспективных способов минимизации влияния углерода на извлечение золота является использование азотной кислоты, поскольку данный реагент может, с одной стороны, интенсифицировать процесс окисления или удаления углеродистого вещества, а с другой - запассивировать его поверхность и таким образом значительно снизить сорбиионную активность углеродистого вещества. Актуальность данной работь обусловлена отсутствием в современной золотоизвлекательной промьиленности технологии, позволяющей перерабатьвать высокоуглеродистое сырье и перспективностью применения азотной кислоты в гидрометаллургии золота.

Цель работы заключалась в обосновании значимости применения азотной кислоты в технологии автоклавного окисления упорных золотосодержащих концентратов.

Результаты. Проведен обзор современных методов переработки упорного золота, выявлены основные преимущества и недостатки каждого. Установлено, что ни один из методов не позволяет эфффективно перерабатьвать высокоуглеродистое сырье из-за невысокой степени оксиления/пассивации углеродистого вещества, которое ответственно за протекание процесса прег-роббинга. В работе представлены технологии переработки золотосодержащего сырья в азотнокислых средах, показано, что азотная кислота может использоваться не только как основной окислитель, но также и как катализатор химических реакций окисления и пассиватор поверхности углеродистого вещества. Описанные в работе уникальные свойства азотной кислоты могут быть успешно применены в автоклавной гидрометаллургии золота.
\end{abstract}

\section{Ключевые слова:}

Упорные золотосодержащие руды, автоклавное окисление, биовыщелачивание, окислительный обжие, азотнокислье технологии, нитрат-ионы, органический углерод, углеродистое вещество, прег-роббинг.

\section{Введение}

В мировом минерально-сырьевом комплексе намечается тенденция роста дисбаланса между добычей и приростом балансовых запасов золотосодержащих руд, что создаёт серьёзную проблему для развития экономики. Истощение запасов легкообогатимого сырья вынуждает золотодобывающие компании осваивать технологии переработки руд упорных месторождений $[1,2]$.

В настоящее время более $20 \%$ всех известных в мире запасов золотосодержащих руд представляют собой так называемые «упорные» руды [1-3]. Сегодня золотодобывающие компании сталкиваются с кризисом запасов, и то, что осталось в недрах, становится все сложнее обрабатывать.

Запасы упорного золота, требующие более сложных методов обработки для достижения степени извлечения оксидной руды, соответствуют $24 \%$ текущих запасов золота и $22 \%$ ресурсов золота во всем мире [2]. Несмотря на то, что эти руды имеют более высокое содержание, их можно обрабатывать только с использованием специальных методов предварительной обработки.

\section{Мировой годовой прирост в добыче неупорного и упорного золота}

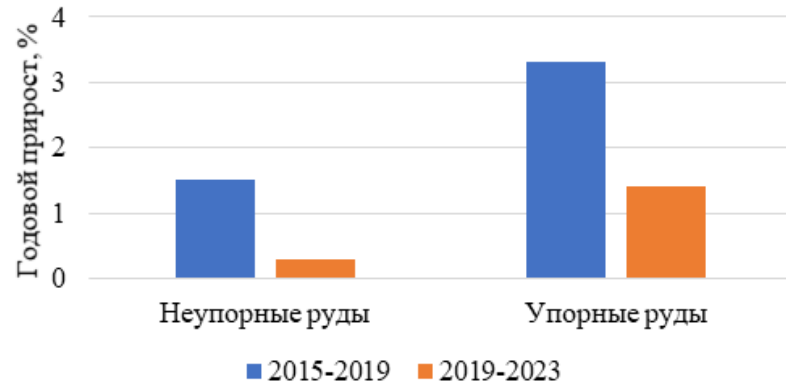

Pис. 1. Годовой прирост в добыче неупорного и упорного золота [4]

Fig. 1. Annual growth in non-refractory and refractory gold production [4] 
Согласно анализу McKinsey [4] в ближайшем будущем ожидается, что добыча на месторождениях упорных руд будет расти более высокими темпами, чем добыча на месторождениях неупорных руд (рис. 1). Современные технологии позволяют извлекать в среднем до $95 \%$ золота из упорных руд, однако ухудшение качества сырья может негативно сказаться на степени извлечения драгоценного металла. Таким образом, необходимо постоянное совершенствование существующих методов и разработка новых технологий, позволяющих извлекать ценные компоненты с максимальной выгодой.

\section{Причины упорности золота}

Основным фактором упорности золотосодержащих руд и концентратов является тонкая диспергация золота в сульфидных минералах, наиболее часто в пирите и арсенопирите. Довольно часто такое сырье также содержит природное органическое углеродистое вещество (УВ), которое способно поглощать растворенные комплексы золота из раствора. Это процесс называется прег-роббингом (preg-robbing) [5, 6]. Наличие УВ придаёт сульфидным золотосодержащим концентратам дополнительную упорность. Такие концентраты часто называют сырьём двойной упорности. Следует отметить, что УВ в каждом материале сильно различается по своей структуре и сорбционным свойствам, наличие органического углерода в руде или концентрате еще не означает потери золота на цианировании.

\section{Первая причина упорности - золото в сульсридах}

Золото, содержащееся в сульфидах, обычно называют «невидимым золотом». Это связано с тем, что его очень трудно обнаружить с помощью оптической микроскопии или сканирующей электронной микроскопии (SEM). Пирит $\left(\mathrm{FeS}_{2}\right)$ является основным золотосодержащим сульфидом этих руд и часто встречается вместе в арсенопиритом (FeAsS). Связь с мышьяком является ещё одним фактором, обуславливающим упорность руды, поскольку наличие мышьяка может вызвать трудности при переработке из-за потенциальных экологических проблем [5]. На рис. 2 показан пример инкапсуляции золота в сульфиды, которая способствует упорности руды.

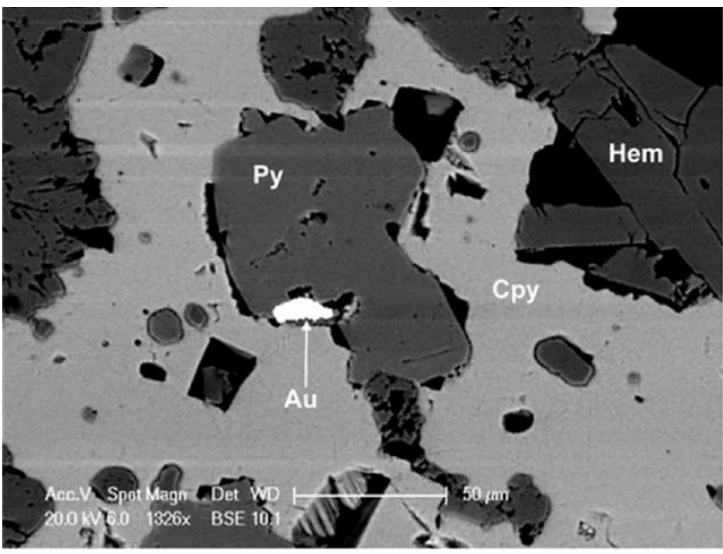

Pис. 2. Пример инкапсуляции золота в сульфидах [5]

Fig. 2. Example of gold encapsulation in sulphides [5]
Прямое цианирование таких материалов дает извлечение на уровне $2-50 \%$. В кристаллической структуре пирита и арсенопирита атомы золота замещают атомы «хозяев» в узлах кристаллической решетки минерала и находятся в дефектах решетки или ее междуузлиях [6]. Таким образом, для того чтобы добыть такое золото, необходимо разрушить кристаллическую решетку минерала.

Спецификой существования частиц золота в кристаллической решётке указанных минералов являются малые размеры их частиц, сопоставимые с размером атомов. В результате эти частицы сильно различаются по физическим и химическим свойствам от более крупных частиц. Одним из проявлений этих различий является большая склонность к окислению по сравнению с компактным металлическим золотом. Принципиально высвободить золото и перевести его в форму, доступную для цианирования, можно путём окисления матрицы минерала, которое достигается автоклавным или биологическим методами, а также обжигом.

Многие сульфидные концентраты после практически полного автоклавного окисления при температуре окисления $200{ }^{\circ} \mathrm{C}$ показывают извлечение золота при последующем цианирования на уровне $94-98$ \%. Подобные золотосодержащие сульфидные материалы называются упорными. Если же в составе перерабатываемого материала присутствует так называемый органический углерод, автоклавное окисление концентрата происходит полностью, но последующее извлечение золота при цианировании полученного продукта падает на 5-50 \% по сравнению с обычными упорными концентратами. Руды и концентраты, обладающие подобными признаками упорности, называют дважды упорными.

Вторая причина упорности - наличие органического углерода

В случае некоторых руд извлечение золота путём цианирования ограничивается присутствием встречающегося в природе углеродистого материала, который адсорбирует золото из цианидного раствора. Чаще всего такие руды относят к материалам с эффектом прег-роббинга. Впервые Смит использовал термин «прег-роббинг» в 1968 г. [7], а позже его использовали и другие учёные и инженеры. Сейчас он широко используется в золотодобывающей промышленности. Прег-роббинг - важное явление, которое препятствует извлечению золота из-за присутствия природного УВ. Оно было обнаружено ещё в 1911 г. Коузом, который понял, что потери золота в хвостохранилищах месторождения Вайхи-Паерола в Новой Зеландии были связаны с присутствием в руде органического углерода [8].

Минералогия, связанная с углеродистыми золотосодержащими рудами, может сильно отличаться в зависимости от месторождения [9]. Составляющие руды, отвечающие за прег-роббинг, обычно представляют собой углеродсодержащие материалы, такие как древесная щепа, некарбонатный углерод, или другие компоненты, в особенности природный углерод в элементной форме [10]. Углеродистый материал 
встречается во многих месторождениях по всему миру. Он образуется в результате твердофазного метаморфического преобразования органического материала, первоначально находившегося в контакте с горной породой. Это превращение называется графитизацией и зависит от температуры, давления и типа предшественника углерода.

Присутствие углеродистого вещества в руде не обязательно приводит к низкому извлечению золота. Похоже, что углерод может существовать в руде в различных формах, которые проявляют различное сродство к растворенному золото-цианидному комплексу. Считается, что природный углерод в углеродистой руде ведёт себя так же, как активированный уголь, при контакте с растворами ауро-цианидов.

Органический углерод, присутствующий во многих золотосодержащих рудах и входящий в состав углеродистого вещества этих руд, как правило, соотносят с тремя основными типами или группами химических соединений:

- кероген;

- углеводороды;

- гуминовые кислоты.

Углеводороды и гуминовые кислоты находят и выделяют из рудного УВ весьма редко и в небольших количествах. При этом отмечают, что углеводороды практически не проявляют сорбционных свойств по отношению к комплексам золота. Гуминовые кислоты, напротив, способны сорбировать золото за счёт функциональных групп.

Основным типом УВ является группа химических соединений, которую можно обозначить как «кероген».

В частности, собственно «керогеном» и аморфным углеродом, очевидно, называют слабопреобразованную фракцию керогена. По мере метаморфизации керогена в ходе геохимических процессов (диагенеза и катагенеза) он теряет функциональные группы, водород и кислород, его структура упорядочивается и становится более кристаллической. В таком случае полученный органический углерод характеризуют как ароматический $\mathrm{C}$ (сравнивая его с антрацитом), кристаллический $\mathrm{C}$, графитный $\mathrm{C}$, углерод типа активированного угля.

Активным - с точки зрения технологии производства золота - является углерод со слаборазвитой кристаллической структурой (аморфный) или же, напротив, сильно преобразованный углерод, но имеющий специфические функциональные группы (преимущественно, кислородсодержащие) или дефекты кристаллической решётки.

Как правило, органический углерод находится в металлургических пробах в рассеянном виде. Его содержание варьируется от десятых долей процента до нескольких процентов и редко превышает 10 \% в рудах и концентратах. К числу наиболее распространённых углеродсодержащих месторождений золота относят, например, руды Карлинского тренда в Неваде, а в РФ и ближнем зарубежье это так называемые «чёрные сланцы» [11].

\section{Современные технологии переработки упорного золота}

Для переработки таких материалов применяются следующие технологии:

Окислительный обжиг материала при температуpax от 400 до $800{ }^{\circ} \mathrm{C}[5,6]$. Данный способ считается первой технологией переработки упорных золотосодержащих концентратов. Извлечение золота варьируется в интервале от 80 до 90 \%. Технология отличается относительной простотой, низкими затратами в случае автогенности процесса и возможностью удаления (выжигания) органического углерода. Однако известны случаи, когда происходила, наоборот, активация поверхности углерода, которая приводила ещё к большим потерям золота на последующем цианировании. К недостаткам технологии относятся высокое содержание токсичных веществ в отходящих газах, особенно при переработке сырья с высоким содержанием мышьяка, сурьмы или ртути; возможность спекания частиц, которое ведёт к снижению извлечения золота и высокие капитальные затраты.

Бактериальное выщелачивание (биовыщелачивание). Сегодня биовыщелачивание - это одна из основных технологий переработки упорного золота $[8,9]$. В мире существует примерно 20 заводов, работающих по данному методу. На территории Российской Федерации до недавнего времени упорные золотосодержащие руды перерабатывались только по технологии бактериального выщелачивания (месторождение «Олимпиада», компания «Полюс Золото») [12]. Бактериальное окисление проводится при температуpax от 30 до $50{ }^{\circ} \mathrm{C}$ и контролируемом значении $\mathrm{pH}$. Температура - один из ключевых факторов процесса, поскольку незначительное изменение температуры может привести к гибели бактерий, и их окислительные свойства снижаются. Продолжительность процесса может достигать 5-6 суток [12]. Извлечение 30лота при биовыщелачивании достигает $95 \%$ [13]. Технология отличается низкими капиталозатратами, отсутствием зависимости от содержания сульфидной серы в исходном сырье (поскольку нет необходимости в поддержании высоких температур). К недостаткам относят образование элементной серы, которая значительно повышает расход цианида при дальнейшей переработке, а также низкую интенсивность процесса.

Атмосферное окисление с предварительным сверхтонким измельчением, процесс Albion [9-11, 14]. Технология процесса Albion была разработана в 1994 г. компанией Xstrata PLC и считается запатентованной по всему миру. На сегодняшний день действуют 4 завода, использующих данную технологию. Первый этап процесса Albion - сверхтонкое измельчение концентрата. Большинство сульфидных минералов невозможно выщелачивать при условиях атмосферного давления. Процесс сверхтонкого измельчения приводит к высокой степени деформации (напряжениям) решётки сульфидного минерала. В результате количество трещин на границах зёрен и дефектов решётки в минерале увеличивается на несколько порядков по сравнению с неизмельчёнными минералами. 
После тонкого измельчения концентрата пульпа выщелачивается в реакторах, кислород при этом вводится в пульпу выщелачивания для окисления сульфидных минералов. Извлечение золота в процессе Albion достигает 90-95\%. Технология отличается низкой скоростью процесса, образованием элементной серы.

Автоклавное окисление [8, 9, 15-20]. Данная технология предполагает окисление упорного золота кислородом под высокими давлением и температурой. Автоклавное окисление применяется для переработки упорных золотосульфидных руд, содержащих пирит, арсенопирит, халькопирит и другие сульфидные минералы. Золото выделяется при последующем циани- ровании автоклавного кека. Технология позволяет извлекать до $99 \%$ золота, отличается высокой интенсивностью процесса, отсутствием образования элементной серы (все сульфиды окисляются до сульфатов), частичной пассивацией или окислением углерода, а также выделением мышьяка в стабильную водонерастворимую форму скородита. К недостаткам технологии относят высокие капитальные затраты и риск протекания автоклавного прег-роббинга [19, 21].

В таблице Таблица представлены основные преимущества и недостатки существующих технологий переработки упорных золотосодержащих руд и концентратов.

Таблица. Преимущества и недостатки основных технологий переработки упорных золотосодержащих концентратов Table. Advantages and disadvantages of the main technologies for processing refractory gold-bearing concentrates

\begin{tabular}{|c|c|c|c|c|}
\hline \multirow[b]{2}{*}{$\begin{array}{l}\text { Критерий/Технология } \\
\text { Criterion/Technology }\end{array}$} & \multirow[b]{2}{*}{ Обжиг/Roasting } & \multirow{2}{*}{$\begin{array}{c}\text { Биовыщелачивание } \\
\text { Bioleaching }\end{array}$} & \multicolumn{2}{|c|}{ Окисление/Oxidation } \\
\hline & & & $\begin{array}{l}\text { aтмосферное } \\
\text { atmosphere }\end{array}$ & $\begin{array}{c}\text { автоклавное } \\
\text { pressure }\end{array}$ \\
\hline $\begin{array}{l}\text { Извлечение } \mathrm{Au}, \% \\
\text { Au recovery, \% }\end{array}$ & $80-90$ & $80-95$ & $90-95$ & $90-99$ \\
\hline $\begin{array}{l}\text { Пассивация/удаление орг. углерода } \\
\text { Passivation/removal of org. carbon }\end{array}$ & $\begin{array}{c}\text { Частичное окисление, } \\
\text { возможна активация } \\
\text { Partial oxidation, activation possible }\end{array}$ & $\begin{array}{c}\text { Частичная } \\
\text { пассивация } \\
\text { Partial passivation }\end{array}$ & $\begin{array}{l}\text { Отсутствует } \\
\text { Absent }\end{array}$ & $\begin{array}{c}\text { Частичное } \\
\text { окисление } \\
\text { Partial oxidation }\end{array}$ \\
\hline $\begin{array}{l}\text { Образование элементной серы } \\
\text { Elemental sulfur formation }\end{array}$ & $\begin{array}{c}\text { Отсутствует } \\
\text { Absent }\end{array}$ & $\begin{array}{l}\text { Присутствует } \\
\text { Present }\end{array}$ & $\begin{array}{l}\text { Присутствует } \\
\text { Present }\end{array}$ & $\begin{array}{c}\text { Отсутствует } \\
\text { Absent }\end{array}$ \\
\hline $\begin{array}{l}\text { Интенсивность процесса } \\
\text { Process intensity }\end{array}$ & $\begin{array}{c}\text { Высокая } \\
\text { High }\end{array}$ & $\begin{array}{l}\text { Низкая } \\
\text { Low }\end{array}$ & $\begin{array}{l}\text { Низкая } \\
\text { Low }\end{array}$ & $\begin{array}{c}\text { Высокая } \\
\text { High }\end{array}$ \\
\hline $\begin{array}{l}\text { Экологичность } \\
\text { Environmental friendliness }\end{array}$ & $\begin{array}{l}\text { Низкая } \\
\text { Low }\end{array}$ & $\begin{array}{c}\text { Высокая } \\
\text { High }\end{array}$ & $\begin{array}{c}\text { Высокая } \\
\text { High }\end{array}$ & $\begin{array}{c}\text { Высокая } \\
\text { High }\end{array}$ \\
\hline $\begin{array}{l}\text { Капиталоёмкость } \\
\text { САРЕХ }\end{array}$ & $\begin{array}{l}\text { Высокая } \\
\text { High }\end{array}$ & $\begin{array}{l}\text { Низкая } \\
\text { Low }\end{array}$ & $\begin{array}{l}\text { Низкая } \\
\text { Low }\end{array}$ & $\begin{array}{c}\text { Высокая } \\
\text { High }\end{array}$ \\
\hline
\end{tabular}

Информация, представленная в таблице, доказывает востребованность автоклавной технологии по сравнению с другими. По данным Global Mining Research на автоклавный метод приходится 18 \% всего добываемого золота в мире.

Все вышеперечисленные технологии переработки упорного золота позволяют практически полностью разрушить сульфидную матрицу и извлечь золото с минимальными потерями (до $99 \%$ ).

Однако вторая причина упорности до сих пор представляет собой серьёзную проблему, поскольку наличие активного органического углерода в исходном материале может привести к значительным потерям золота. Особенно данная проблема актуальна в автоклавной гидрометаллургии, где различают два вида прег-роббинга. Первый проявляется в процессе автоклавного окисления и представляет собой сорбцию золото-хлоридного комплекса на поверхности УВ, поскольку в автоклавных условиях при наличии в пульпе хлорид-иона золото способно растворяться с образованием ауро-хлоридных комплексов, которые затем поглощаются УВ, данный вид прег-роббинга в литературе называется хлоридным или автоклавным. Второй вид прег-роббинга происходит при цианировании, где золото-цианидный комплекс также сорбируется на поверхности УВ. Сорбированное золото в обоих видах прег-роббинга уходит в хвосты и не извлекается.
Таким образом, в автоклавной технологии проблема прег-роббинга наиболее актуальна, поскольку другие методы переработки упорного золота предполагают либо значительное окисление, т. е. удаление, органического углерода (обжиг), либо частичное окисление с пассивацией его поверхности (биовыщелачивание, азотнокислая переработка).

На сегодняшний день для борьбы с органическим углеродом в золотосодержащих концентратах существует множество способов: цианирование с использованием сорбентов (процесс CIL/RIL); термическая обработка концентрата или кека автоклавного выщелачивания [22, 23]; очистка воды от хлора; повышение температуры автоклавного окисления (до $250{ }^{\circ} \mathrm{C}$ ) и времени пребывания материала в автоклаве [24]; добавки солей серебра и ртути для связывания ионов хлора в автоклавном растворе [25]; использование окислителей для окисления углерода и пассивации его поверхности [26]; использование поверхностноактивных добавок, которые снижают адсорбционную способность углерода [27, 28]; тиосульфатное выщелачивание [29]; каталитическое добавление ионов меди [30].

Одним из наиболее интересных и перспективных вышеперечисленных способов в снижении сорбционной активности углерода является его пассивация растворами азотной кислоты [25], поскольку, с одной стороны, азотная кислота может быть использована для пассивации поверхности, а с другой - для окис- 
ления углерода. В рамках данной статьи будет рассмотрена возможность использования азотной кислоты для снижения степени автоклавного и цианидного прег-роббинга.

\section{Использование $\mathrm{HNO}_{3}$ для переработки} упорных золотосодержащих концентратов

Азотнокислое выщелачивание золотосодержащих концентратов

Применение азотнокислых растворов при выщелачивании сульфидов цветных металлов характеризуется высокими значениями окислительного потенциала что выгодно отличает азотную кислоту от более распространённых серно- и солянокислых реагентов. Азотная кислота в данном случае - это уникальный реагент, поскольку может быть не только окислителем, но и катализатором реакции окисления.

К наиболее известным технологиям переработки сульфидных золотосодержащих материалов относят Nitrox, Redox.

При азотнокислом выщелачивании сульфидов цветных металлов с последующей регенерацией азотной кислоты в общем виде протекают следующие типовые реакции:

$$
\begin{gathered}
\mathrm{MeS}+8 \mathrm{HNO}_{3}=\mathrm{Me}\left(\mathrm{NO}_{3}\right)_{2}+\mathrm{H}_{2} \mathrm{O}+\mathrm{NO}_{(\mathrm{g})}+\mathrm{SO}_{4}{ }^{2} ; \\
\mathrm{Me}: \mathrm{Cu}, \mathrm{Pb}, \mathrm{Zn}, \mathrm{Ag} \text { и т. д.; } \\
2 \mathrm{FeS}_{2}+10 \mathrm{HNO}_{3} \rightarrow 2 \mathrm{Fe}^{3+}+2 \mathrm{H}^{+}+4 \mathrm{SO}_{4}{ }^{2-}+10 \mathrm{NO}+4 \mathrm{H}_{2} \mathrm{O} ; \\
3 \mathrm{FeAsS}+12 \mathrm{HNO}_{3} \rightarrow 3 \mathrm{FeAsO}_{4}+4 \mathrm{H}^{+}+2 \mathrm{SO}_{4}{ }^{2-}+4 \mathrm{H}_{2} \mathrm{O}+\mathrm{S}+12 \mathrm{NO} .
\end{gathered}
$$

Результаты лабораторных исследований по азотнокислому выщелачиванию сульфидных материалов представлены в работах [31, 32]. В статье [32] исследовалось влияние предварительной азотнокислой обработки упорного золотосульфидного концентрата, содержащего 62 г/т золота; 17,9 \% сульфидной серы и $0,9 \%$ углерода (карбонатный+органический). Азотнокислое выщелачивание проводилось при температуре $80^{\circ} \mathrm{C}$ в течение 150 минут, концентрация азотной кислоты составляла 5 моль/л.

Дальнейшее цианирование проводилось при комнатной температуре в течение 24 часов. Ж:Т пульпы $=4$, концентрация $\mathrm{NaCN}=1,5$ г/л.

Результаты исследований, представленных в [32], показаны на рис. 3.

На рисунке показано, что прямое цианирование в течение 24 часов позволяет извлечь лишь 40 \% золота, что подтверждает факт упорности материала. Предварительная обработка азотной кислотой способствует увеличению извлечения золота до 99 \%. Очевидно, что в описанных технологиях либо органический углерод, входящий в состав концентрата, отличается минимальной сорбционной активностью, либо происходит пассивация его поверхности. Окисление углерода в таких условиях маловероятно. Неясно, как данная технология покажет себя на концентратах, где содержание органического углерода будет более $1 \%$.

Использование азотной кислоты в качестве основного окислительного агента - хорошо изученный процесс, имеющий свои особенности, связанные с высоким расходом азотной кислоты, выбросом газо- образных соединений азота в атмосферу, сложностью организации регенерации кислоты и т. д.

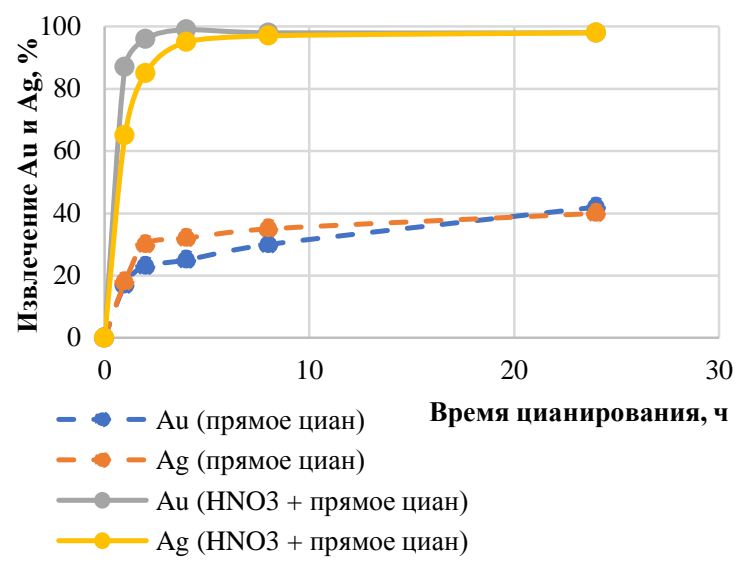

Рис. 3. Результаты опытов по азотнокислому выщелачиванию [32]

Fig. 3. Experiments results of nitric acid leching [32]

Использование $\mathrm{HNO}_{3}$ в качестве катализатора

Также известно, что использование азотной кислоты в качестве катализатора способствует ускорению процесса окисления, одним из примеров таких технологий является NSC [33]. Преимущества данной технологии:

- повышение скорости реакции окисления;

- меньший объем реактора;

- процесс не требует высоких температур и давления;

- за счёт высокого ОВП, который достигается добавлением азотной кислоты, возможно окисление при низком избыточном давлении кислорода;

- низкие капитальные затраты на строительство и обслуживание реактора, поскольку в качестве материала изготовления может быть использована нержавеющая сталь без защитных слоев кислотостойкого кирпича или титана;

- отсутствует риск возгорания титана.

Общепринятая форма реакция окисления сульфидов серной кислотой в соединении с азотной выглядит следующим образом:

$$
\begin{aligned}
& 3 \mathrm{MeS}_{(\mathrm{s})}+2 \mathrm{HNO}_{3(\mathrm{aq})}+3 \mathrm{H}_{2} \mathrm{SO}_{4(\mathrm{aq})} \rightarrow \\
& \rightarrow 3 \mathrm{MeSO}_{4}+3 \mathrm{~S}_{(\mathrm{s})}^{0}+2 \mathrm{NO}_{(\mathrm{g})}+4 \mathrm{H}_{2} \mathrm{O} .
\end{aligned}
$$

Однако считается, что реакционной формой является $\mathrm{NO}^{+}$вместо $\mathrm{NO}_{3}^{-}$. Добавка ионов $\mathrm{NO}_{2}^{-}$ускоряет процесс образования $\mathrm{NO}^{+}$. В качестве источников $\mathrm{NO}_{2}^{-}$могут быть использованы нитриты калия, натрия.

Как показано в реакции (1) в процессе окисления сульфидов образуется газ NO. Данный газ имеет лимитированное значение растворимости в воде, ввиду чего перемещается из раствора. В закрытом реакторе в условиях избыточного давления кислорода происходят следующие реакции:

$$
\begin{gathered}
2 \mathrm{NO}_{(\mathrm{g})}+\mathrm{O}_{2(\mathrm{~g})} \leftrightarrow 2 \mathrm{NO}_{2(\mathrm{~g})} ; \\
2 \mathrm{NO}_{2(\mathrm{~g})} \leftrightarrow 2 \mathrm{NO}_{2(\mathrm{aq})} ;
\end{gathered}
$$




$$
2 \mathrm{NO}_{2(\mathrm{aq})}+2 \mathrm{NO}_{(\mathrm{aq})}+4 \mathrm{H}^{+} \leftrightarrow \mathrm{NO}_{(\text {(aq })}^{+}+2 \mathrm{H}_{2} \mathrm{O}
$$

Поскольку соединения азота в процессе окисления регенерируются, их роль в суммарной реакции как фактического окислителя неочевидна. Общая суммарная реакция (2) представляет собой взаимодействие сульфидного минерала с раствором кислоты, в результате которой образуются растворимые сульфаты и некоторые количества элементарной серы. Конечно, при более высоких температурах и/или концентрациях азотной кислоты сульфид будет полностью окисляться до сульфата.

$$
2 \mathrm{MeS}_{(\mathrm{s})}+4 \mathrm{H}^{+}+\mathrm{O}_{2(\mathrm{~g})} \rightarrow 2 \mathrm{Me}^{2+}{ }_{(\mathrm{qq})}+2 \mathrm{~S}^{0}+2 \mathrm{H}_{2} \mathrm{O} .
$$

Промежуточные продукты азота служат подходящим средством для переноса кислорода к поверхности твёрдых частиц и позволяют полученной реакции протекать с повышенным окислительно-восстановительным потенциалом. Это уникальное явление исключает использование высоких температур и высоких давлений. В таких процессах в качестве корпуса реактора может быть использована обычная нержавеющая сталь. Таким образом, быстрая кинетика системы приводит к меньшим объёмам реактора и более высокой производительности. 99,9 \% видов азота, используемых в системе выщелачивания, утилизируются в газовой фазе и легко разрушаются и удерживаются коммерчески доступными системами скрубберов. Таким образом, воздействие на окружающую среду сводится к минимуму, и растворы автоклавного выщелачивания практически не содержат азота.

Технология NSC была промышленно применена на медно-серебряном концентрате на металлургическом комплексе Sunshine [34]. Исходный химический состав перерабатываемого концентрата: $24 \% \mathrm{Cu} ; 4 \%$ $\mathrm{Ag} ; 35 \% \mathrm{~S}$.

Выщелачивание велось в два этапа, предварительная обработка проводилась при температуре $50{ }^{\circ} \mathrm{C}$ и концентрации серной кислоты 200 г/л. Далее полученная пульпа направлялась на вторую стадию окисления в автоклавных условиях при температуре $155^{\circ} \mathrm{C}$, давлении кислорода 4 бара, концентрация нитрат ионов в исходной пульпе, поступающей на АОВ, составляла 2 г/л.

Извлечение меди и серебра в раствор составило 99 и $96 \%$, соответственно.

Также технология NSC была опробована на упорных золотосульфидных рудах, которые представлены преимущественно халькопиритом [35]. Содержание золота в исходном концентрате составляло 16,3 г/т; серебра 320,3 г/т. Содержание серы $36 \%$, меди $25 \%$.

Выщелачивание проводили при начальной концентрации серной кислоты 175 г/л. Температура процесса $125^{\circ} \mathrm{C}$, парциальное давление кислорода 5 бар. Добавка нитрат ионов 2 г/л. Продолжительность выщелачивания составляла 25 минут.

В результате выщелачивания серебро переходило в раствор на $97 \%$, медь на 99,5\%, железно на $97 \%$. Золото, которое затем извлекалось путём окисления серы в щелочной среде, концентрировалось в сульфидных гранулах. Сульфидная сера при таких условиях окислялась преимущественно до элементарного состояния (степень извлечения элементарной серы $83,7 \%)$

В патенте [36] представлен способ переработки уранового концентрата в серной кислоте с добавлением каталитического количества азотной кислоты. Добавка $\mathrm{HNO}_{3}$ способствовала смягчению условий выщелачивания упорных минералов до температур $130-140{ }^{\circ} \mathrm{C}$. Смягчение условий было возможно за счет снижения энергии активации процессов окисления. Выделяющиеся в процессе окисления оксиды азота далее окислялись кислородом с образованием азотной кислоты:

$$
\begin{gathered}
2 \mathrm{NO}+3 / 2 \mathrm{O}_{2}+\mathrm{H}_{2} \mathrm{O} \rightarrow 2 \mathrm{HNO}_{3} ; \\
2 \mathrm{NO}+1 / 2 \mathrm{O}_{2}+\mathrm{H}_{2} \mathrm{O} \rightarrow 2 \mathrm{HNO}_{2}+\mathrm{O}_{2} \rightarrow 2 \mathrm{HNO}_{3}
\end{gathered}
$$

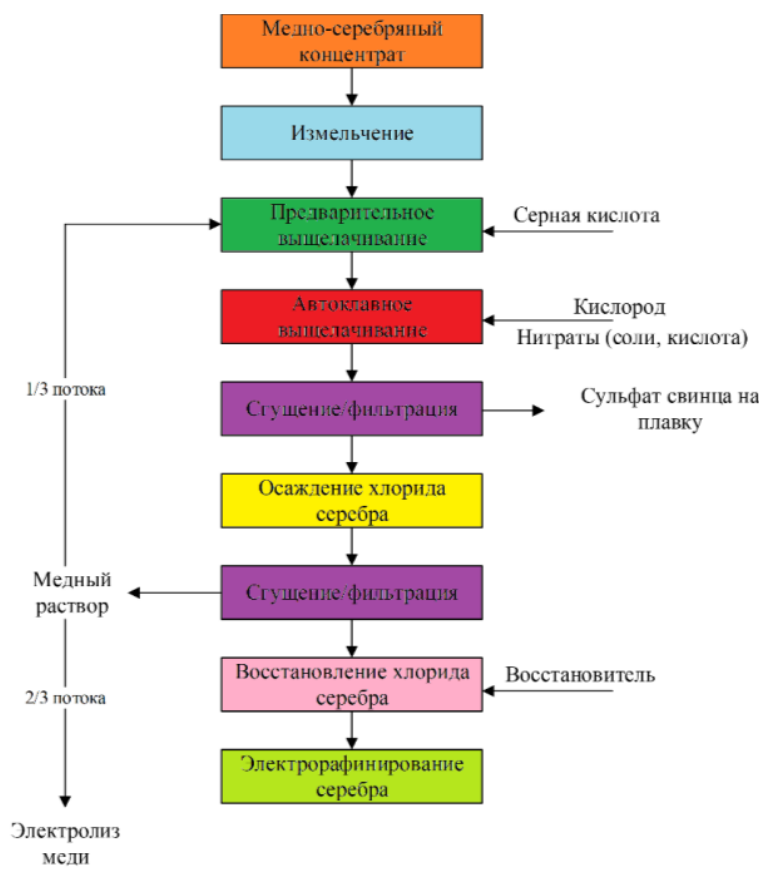

Рис. 4. Технологическая схема переработки медно-серебряного кониентрата на комбинате Sunshine [34]

Fig. 4. Technological processing scheme of copper-silver concentrate at the Sunshine plant [34]

При этом $\mathrm{HNO}_{3}$ регенерируется прямо в реакторе, и процесс протекает без выделения оксидов азота в атмосферу.

В работе [37] каталитическое действие азотной кислоты исследовалось на молибденовых концентратах. Как утверждают авторы, химизм процессов окисления молибденовых минералов аналогичен реакции (2). Добавка $11 \%$ азотной кислоты (от исходной массы сухого концентрата) позволила сократить рабочую температуру процесса с 240 до $180^{\circ} \mathrm{C}$ и избыточное давление кислорода с 4,4 до 2,5 МПа без потерь по извлечению молибдена в раствор и автоклавный кек. Испытания проводились на пилотной автоклавной установке, состоящей из 4 автоклавов по 25 литров.

Таким образом, технологии с использованием азотной кислоты в качестве катализатора доказали свою эффективность и нашли широкое применение в металлургии цветных и благородных металлов. 


\section{Пассивация углеродистого вещества азотной кислотой}

Азотная кислота не только позволяет снизить энергию активации реакции окисления, но также способствует пассивации УВ, которое может оказывать негативный эффект на золотосульфидные руды и концентраты. Данное явление было описано в работе [8].

Поверхностные комплексы кислорода образуются на активированных углях, когда они обрабатываются окислителями либо в газовой фазе, либо в растворе. В результате обработки образуются три типа поверхностных оксидов: кислотный, основной и нейтральный. Одним из способов введения преимущественно кислых поверхностных оксидов, то есть карбоксильных, фенольных и лактонных групп, является обработка активированных углей различными окислительными растворами. В дополнение к этим кислотным группам также вводятся основные и нейтральные поверхностные группы, которые выделяют СО после нагревания при высокой температуре. Фиксация кислотных групп на поверхности активированных углей делает их более гидрофильным, снижает их $\mathrm{pH}$ в точке нулевого заряда и увеличивает отрицательный поверхностный заряд в течение некоторого времени. В то же время вышеуказанные обработки могут повлиять на площадь поверхности и текстуру пор активированных углей.

В работе [38] исследуется механизм пассивации активированного углерода за счет предварительной обработки азотной кислотой, которая позволила снизить количество и размер пор активированного угля и сорбционную активность. Предварительная обработка проводилась следующим образом: 1 г активированного углерода обрабатывался 10 мл концентрированной азотной кислоты при $80^{\circ} \mathrm{C}$ до полной выпарки азотной кислоты. В работе доказано, что в процессе азотнокислой обработки на поверхности углерода фиксируются молекулы кислорода, которые блокируют дальнейшую сорбцию золота.

\section{СПИСОК ЛИТЕРАТУРЫ}

1. Лоза А.И. Обзор золотодобывающей отрасли России по итогам 2019 года - первого полугодия 2020 года // Союз золотопромышленников. - 2020. - № 1. - С. 1-62.

2. Motta G., Polcyn M., Saragosa E. Refractory gold ores: challenges and opportunities for a key source of growth // MineSpans Commentary. - 2021. - № 6. - P. 1-6.

3. Лодейщиков В.В. Состояние и тенденции развития технологии извлечения золота из упорных руд и концентратов // Цветная металлургия. - 1993. - № 2. - С. 4-9.

4. Goode J.R. Refractory gold ore: cause, processes, testing and plants // Proceedings Annual SME Conference. - Colorado, 1993. - P. 82-93.

5. Воробьев-Десятовский Н.В., Епифанов А.В. Автоклавное окисление дважды упорных золотосодержащих руд. Проблемы и пути решения // Минерально-сырьевой комплекс России - новые рубежи и вызовы: 10 Горнопромышленный форум. МАЙНЕКС Россия 2014. - М., 2014. - С. 1-8.

6. Aleksandrova T.N., Heide G., Afanasova A.V. Assessment of refractory gold-bearing ores based of interpretation of thermal analysis data // Journal of Mining Institute. - 2019. - № 235. - P. 30-37.

7. Rees K.L., Deventer V. Preg-robbing phenomena in the cyanidation of sulfide gold ores // Hydrometallurgy. - 2000. № 58. - P. 61-80

8. Miller J. D., Wan R.-Y., Díaz X. Preg-robbing gold ores // Gold Ore Processing. - 2016. - V. 15 - P. 885-907.
В работе [39] показано, что обработка азотной кислотой позволяет снизить сорбционную активность активированного углерода с 87 до $22 \%$. Поскольку активное углеродистое вещество в золотосодержащих рудах химически эквивалентно активированному углю, ожидается, что уменьшение адсорбции золота, наблюдаемое для активированного угля, обработанного азотной кислотой, также будет иметь место в случае углеродистого вещества в руде/концентрате.

\section{Заключение}

Азотная кислота не только позволяет ускорить процесс окисления, но также пассивирует поверхность органического углерода, содержащегося в исходном материале. Эти свойства могут быть успешно использованы в металлургии упорных золотосульфидных руд и концентратов.

Технологии переработки упорных золотосодержащих концентратов с использованием азотной кислоты в качестве основного окислителя широко не востребованы ввиду высокого расхода азотной кислоты, необходимости ее регенерации и утилизации токсичных газов. Методы переработки в смесях азотной и серной кислот, где $\mathrm{HNO}_{3}$ выступает в качестве катализатора химической реакции окисления сульфидов, отличаются множеством преимуществ, однако вопрос пассивации или окисления органического углерода, ответственного за прег-роббинг, остаётся открытым.

Автоклавные технологии переработки упорного золота сегодня применяются наиболее часто, до $18 \%$ от всех методов извлечения золота. Автоклавное окисление позволяет практически полностью разрушить сульфидную матрицу (до 99,9 \%) и высвободить золото, однако степень окисления углерода при этом невысокая. Использование азотной кислоты в качестве вторичного окислителя теоретически может решить проблему прег-роббинга либо за счёт пассивации его поверхности, либо за счёт его окисления.

9. Adams M.D. Summary of gold plants and processers // Advances in gold ore processing. - 2005. - V. 15 - P. 994-1013.

10. Albion process // Albion Process: simplicity in leaching. 1994. URL: https://www.albionprocess.com/ru/about/Pages/oxidativeleaching.aspx (дата обращения: 20.05.2021).

11. Commissioning and ramp-up of the Albion process at the GPM gold project / P. Voigt, M Hourn., D. Mallah, D. Turner // MetPlant 2015. - Perth, 2015. - P. 207-219.

12. Miller P., Brown A. Bacterial oxidation of refractory gold concentrates // Developments in Mineral Processing. - 2005. № 15. - P. 371-402.

13. Bulaev A.G., Boduen A.Y., Ukraintsev I.V. Biooxidation of persistent gold-bearing ore concentrate of the Bestobe deposit // Obogashchenie Rud. - 2019. - № 6. - P. 9-14.

14. Boduen A.Y., Fokina S.B., Polezhaev S.Y. The hydrometallurgical pretreatment of a refractory gold sulfide concentrate // InnovationBased Development of the Mineral Resources Sector: Challenges and Prospects - 11th conference of the Russian-German Raw Materials. - St-Petersburg, 2019. - P. 331-340.

15. Масленицкий И.Н. Опыт автоклавного окисления сульфидных золотосодержащих концентратов перед цианированием // Известия вузов. Цветная металлургия. - 1958. - № 4. - С. 103-108.

16. Ласкорин Б.Н., Чугаев Л.В., Москвина Г.И. Автоклавное окисление сульфидно-мышьяковых концентратов // Гидрометаллургия золота. - М.: Наука, 1980. - С. 52-58. 
17. Автоклавные процессы переработки золотосодержащих концентратов / Л.В. Чугаев, Я.М. Шнеерсон, М.В. Никитин, Н.Ф. Иванова // Цветные металлы. - 1998. - № 2. - С. 56-60.

18. Thomas K.G. Pressure oxidation overview // Developments in Mineral Processing. - 2005. - № 15. - P. 403-432.

19. Седельникова Г.В. Автоклавное и бактериальное выщелачивание упорных золотосульфидных руд и концентратов. Состояние и перспективы применения в отечественной промышленности // Инновационные процессы комплексной и глубокой переработки минерального сырья. Плаксинские чтения2013. Материалы Международного совещания. - Томск, 2013. - C. $28-33$

20. Автоклавная гидрометаллургия цветных металлов / С.С. Набойченко, Я.М. Шнеерсон, М.И. Калашникова, Л.В. Чугаев. - М.: ГОУ ВПО УГТУ-УПИ, 2009. - Т. 2. - С. 351-382.

21. Thermophilic Microbial of Precious Metal Ores: US Patent 4729788. - 1988 .

22. Применение термической обработки для золотосодержащего сырья двойной упорности / С.И. Лаевский, Я.М. Шнеерсон Л.В. Чугаев, М.А. Плешков, А.В. Маркелов, С.Ю. Полежаев // Цветные металлы и минералы 2019: сборник докладов. Красноярск, 2019. - С. 956-963.

23. Полежаев С.Ю., Черемисина О.В. Комплексная технология переработки золотосодержащих концентратов: автоклавное выщелачивание с последующим обжигом // Известия вузов. Цветная металлургия. - 2015. - № 3. - С. 34-39.

24. Высокотемпературное автоклавное окисление сырья двойной упорности / И.В. Фоменко, М.А. Плешков, С.И. Лях, С.И. Лаевский // Цветные металлы. - 2020. - № 9. - С. 110-116.

25. The use of special additives to inhibit preg-robbing of gold in the process of double refractory concentrates pressure oxidation $/$ I.V. Fomenko, M.A. Pleshkov, P.V. Zaytsev, L.V. Chugaev, Y.M. Shneerson // Alta 2016 Gold-PM Session. - Perth, 2016. P. 231-241

26. Method to improve recovery of gold from double refractory gold ores: US Patent 8262768B2. - 2012.

27. The use of special additives to inhibit preg-robbing of gold in the process of double refractory concentrates pressure oxidation / I.V. Fomenko, M.A. Pleshkov, P.V. Zaytsev, L.V. Chugaev, Y.M. Shneerson // Alta 2016 Gold-PM Session. - Perth, 2016. P. 231-241

28. Flash chlorinationa new process for treatment of refractory sulphide and carbonceous gold ores / K.A. Brunk, G. Ramadorai, D. Seymour, F.P. Traczyk // Proceedings of Randol Gold Forum. Golden, CO: Randol International Ltd., 1988. - P. 127-129.
29. Adams M.D., Burger A.M. Characterization and blinding of carbonaceous preg-robbers in gold ores // Minerals Engineering. 1998. - № 11. - P. 919-927.

30. Thiosulfate leaching for gold hydrometallurgy / C. Abruzzese, P. Fornari, R. Massidda, F. Veglio, S. Ubaldini // Hydrometallurgy. - 1995. - № 39. - P. 265-276.

31. A hydrometallurgical process for the recovery of precious metals from ores: US Patent 05354359. - 1994

32. Oktay C., Ersin Y.Y., Haci D. A preliminary study on nitric acid pre-treatment of refractory gold/silver ores // 25th International Mining Congress and Exhibition of Turkey (IMCET). - Antalya, 2017. - P. 463-468.

33. Rusalev R.E., Rogozhnikov D.A., Naboichenko S.S. Nitric acid treatment of Olympiada deposit refractory gold-bearing concentrate // International Russian Conference on Materials Science and Metallurgical Technology. - Vladivostok, 2018. P. 541-546.

34. Anderson C.G. Applications of NSC pressure leaching // Pressure Hydrometallurgy. - 2004. - V. 3 - P. 855-886.

35. Hydrometallurgy at the Sunshine metallurgical complex / J.B. Ackerman, C.G. Anderson, S.M. Nordwick, L.E. Krys // Proceedings of the Fourth International Symposium on Hydrometallurgy. - Litleton, Colorado, SME, 1993. - P. 477-496.

36. Anderson C.G. The application and economics of industrial NSC pressure leaching to copper ores and concentrates // COBRE 2003. - Santiago, 2003. - P. 1-15.

37. Способ переработки упорных урановых содержащих пирит и благородные металлы материалов для извлечения урана и получения концентрата благородных металлов: пат. 2398903 C1, Рос. Федерация; заявл. 30.03.2009; опубл. 10.09.2010, Бюл. № $25 .-16 \mathrm{c}$.

38. Autoclave leaching of molybdenite concentrates with catalytic additives of nitric acid / K.M. Smirnov, N.A. Raspopov, Y.M. Shneerson, A.Y. Lapin // Russian Metallurgy (Metally). 2009. - № 7. - P. 588-595.

39. Activated carbon surface modifications by nitric acid, hydrogen peroxide, and ammonium peroxydiate treatments / C. MorenoCastilla, M.A. Ferro-García, J.P. Joly, I. Bautista-Toledo, F. Carrasco-Marín, J. Rivera-Utrilla // Langmuir. - 1995. № 11. - P. 4386-4392.

40. Díaz X., Snihvrowych M. MAC's with nitric acid pretreatment. Internal report. - Utah: University of Utah, 2004 - 7 p.

Поступила 27.06.2021 г.

\section{Информация об авторах}

Гордеев Д.В., аспирант кафедры металлургии, Санкт-Петербургский Горный университет.

Петров Г.В., доктор технических наук, профессор кафедры металлургии, Санкт-Петербургский Горный университет.

Хасанов A.B., аспирант кафедры металлургии, Санкт-Петербургский Горный университет.

Северинова O.B., магистрант кафедры металлургии, Санкт-Петербургский Горный университет. 
UDC 669.053.4

\title{
REVIEW OF MODERN PROCESSING TECHNOLOGIES OF REFRACTORY GOLD ORES AND CONCENTRATES WITH USE OF NITRIC ACID
}

\author{
Daniil V. Gordeev ${ }^{1}$ \\ danya.gordeev.2014@mail.ru
}

Georgiy V. Petrov'1, petroffg@yandex.ru

Arthur V. Khasanov ${ }^{1}$ khasanov-a@gidrometall.ru

Olga V. Severinova ${ }^{1}$, argentumhelga@gmail.com

1 Saint-Petersburg Mining University, 2, $21^{\text {st }}$ Line, Saint-Petersburg, 199106, Russia.

The relevance. The refractoriness of gold-bearing ores is caused by two factors: the first is the fine dispersion of gold in sulfide minerals, and the second is the presence of carbonaceous matter, which is responsible for the pre-robbing, leading to an inevitable decrease in gold recovery. In the modern gold mining industry, there are many ways to process refractory gold with carbonaceous matter content up to $1 \%$, but its higher concentrations still cause big problems. One of the most interesting and promising ways to minimize the effect of carbon on gold recovery is the use of nitric acid, since this reagent can, on the one hand, intensify oxidation or removal of carbonaceous matter, and, on the other hand, passivate its surface and, thus, significantly reduce the sorption activity of carbonaceous matter. The relevance of this work is caused by the lack of technology in the modern gold mining industry that allows processing high carbonaceous raw materials and the promising use of nitric acid in gold hydrometallurgy.

The aim of the work was to substantiate the importance of using nitric acid in the technology of autoclave oxidation of refractory goldbearing concentrates.

Results. The authors have carried out a review of modern methods of refractory gold processing, the main advantages and disadvantages of each were identified. It was found that none of the methods allows efficient processing of high-carbonaceous raw materials due to the low degree of carbonaceous matter oxidation/passivation, which is responsible for the pre-robbing process. The paper presents technologies for processing gold-bearing raw materials in nitric acid media; it is shown that nitric acid can be used not only as the main oxidant, but also as a catalyst for chemical oxidation reactions and a passivator of the carbonaceous matter surface. The unique properties of nitric acid described in the work can be successfully applied in the autoclave hydrometallurgy of gold.

\section{Key words:}

Refractory gold-bearing ores, autoclave oxidation, bioleaching, oxidative roasting, nitric acid technologies, nitrate ions, organic carbon, carbonaceous matter, preg-robbing.

\section{REFERENCES}

1. Loza A.I. Overview of the gold mining industry in Russia at the end of 2019 - the first half of 2020. Union of Gold Producers, 2020, no. 1, pp. 1- 62. In Rus.

2. Motta G., Polcyn M., Saragosa E. Refractory gold ores: challenges and opportunities for a key source of growth. MineSpans Commentary, 2021, no. 6, pp. 1-6.

3. Lodeyshchikov V.V. State and development trends of technology for extracting gold from refractory ores and concentrates. Nonferrous metallurgy, 1993, no. 2, pp. 4-9. In Rus.

4. Goode J.R. Refractory gold ore: cause, processes, testing an plants. Proceedings Annual SME Conference. Colorado, 1993. pp. 82-93.

5. Vorobiev-Desyatovsky N.V., Epifanov A.V. Avtoklavnoe okislenie dvazdy upornykh zolotosoderzashchikh rud. Problemy i resheniya [Autoclave oxidation of doubly refractory gold-bearing ores. Problems and solutions]. Mineralno-syrevoy kompleks Rossii - novye rubezhi $i$ vyzovy. 10 Gornopromyshlenny forum. MAJNEKS Rossiya [10 Mining Forum. Mineral and Raw Materials Complex of Russia - New Frontiers and Challenges. MINEX Russia 2014]. Moscow, 2014. pp. 1-8.

6. Aleksandrova T.N., Heide G., Afanasova A.V. Assessment of refractory gold-bearing ores based of interpretation of thermal analysis data. Journal of Mining Institute, 2019, no. 235, pp. 30-37.

7. Rees K.L., Deventer V. Preg-robbing phenomena in the cyanidation of sulfide gold ores. Hydrometallurgy, 2000, no. 58, pp. 61-80

8. Miller J. D., Wan R.-Y., Díaz X. Preg-robbing gold ores. Gold Ore Processing, 2016, vol. 15, pp. 885-907.
9. Adams M.D. Summary of gold plants and processers. Advances in gold ore processing, 2005, vol. 15, pp. 994-1013.

10. Albion process. Albion Process: simplicity in leaching. 1994. Available at: https://www.albionprocess.com/ru/about/ Pages/ oxidative-leaching.aspx (accessed 20 May 2021).

11. Voigt P., Hourn M., Mallah D., Turner D. Commissioning and ramp-up of the Albion process at the GPM gold project. MetPlant 2015. Perth, 2015. pp. 207-219.

12. Miller P., Brown A. Bacterial oxidation of refractory gold concentrates. Developments in Mineral Processing, 2005, no. 15, pp. 371-402.

13. Bulaev A.G., Boduen, A.Y., Ukraintsev, I.V. Biooxidation of persistent gold-bearing ore concentrate of the Bestobe deposit. Obogashchenie Rud, 2019, no. 6, pp. 9-14.

14. Boduen A.Y., Fokina S.B., Polezhaev S.Y. The hydrometallurgical pretreatment of a refractory gold sulfide concentrate. InnovationBased Development of the Mineral Resources Sector: Challenges and Prospects $-11^{\text {th }}$ conference of the Russian-German Raw Materials. St-Petersburg, 2019. pp. 331-340.

15. Maslenitsky I.N. Opyt avtoklavnogo okisleniya sulfidnykh zolotosoderzhashchikh kontsentratov pered tsianirovaniem [Experience of autoclave oxidation of sulfide gold-containing concentrates before cyanidation]. Izvestiya vuzov. Cvetnatnay metallurgia, 1958, no. 4, pp. 103-108

16. Laskorin B.N., Chugaev L.V., Moskvina G.I. Avtoklavnoe okislenie sulfidno-myshyakovykh kontsentratov [Autoclave oxidation of arsenic sulfide concentrates]. Gidrometallurgiya zolota [Gold hydrometallurgy]. Moscow, Nauka Publ., 1980. pp. 52-58. 
17. Chugaev L.V., Shneerson Ya.M., Nikitin M.V., Ivanova N.F. Avtoklavnoe okislenie sulfidno-myshyakovykhkontsentratov [Autoclave oxidation of gold-containing concentrates]. Non-ferrous metals, 1998, no. 2, pp. 56-60.

18. Thomas K.G. Pressure oxidation overview. Developments in Mineral Processing, 2005, no. 15, pp. 403-432.

19. Sedelnikova G.V. Avtoklavnoe i bakterialnoe vyshchelachivanie upornykh zolotosulfidnykh rud i kontsentratov. Sostoyanie i perspektivy primeneniya $\mathrm{v}$ otechestvennoy promyshlennosti [Autoclave and bacterial leaching of refractory gold sulfide ores and concentrates. State and prospects of application in the domestic industry]. Innovacionnye protsessy kompleksnoy i glubokoy pere rabotki mineralnogo syrya. Plaksinskie chteniya - 2013 [Innovative processes of complex and deep processing of mineral raw materials. Plaksin Readings 2013]. Tomsk, 2013. pp. 28-33.

20. Naboychenko S.S., Shneerson Ya.M., Kalashnikova M.I., Chugaev L.V. Avtoklavnaya gidrometallurgia tsvetnykh metallov [Autoclave hydrometallurgy of non-ferrous metals]. Moscow, GOU VPO USTU-UPI Publ., 2009. Vol. 2, pp. 351-382.

21. Hutchins S.R., Davidson J.A., Brierley J.A., Brierley C.L. Thermophilic Microbial of Precious Metal Ores. US Patent, no. 4729788,1988

22. Laevsky S.I., Shneerson Ya.M., Chugaev L.V., Pleshkov M.A., Markelov A.V., Polezhaev S.Yu. Primenenie termicheskoy obrabotki dlya zolotosoderzhashchego syrya dvoynoy upornosti [The use of heat treatment for gold-bearing raw materials of double persistence]. Cvetnye metally i mineraly 2019: sbornik dokladov [Non-ferrous metals and minerals 2019: collection of reports]. Krasnoyarsk, 2019. pp. 956-963.

23. Polezhaev S.Yu., Cheremisina O.V. Integrated technology for processing gold-containing concentrates: autoclave leaching with subsequent roasting. Russian Journal of Non-Ferrous Metals, 2015, no. 3, pp. 34-39. In Rus.

24. Fomenko I.V., Pleshkov M.A., Lyakh S.I., Laevsky S.I. Hightemperature autoclave oxidation of double refractory raw materials. Non-ferrous metals, 2020, no. 9, pp. 110-116. In Rus.

25. Gorain B., Condos P. Method to improve recovery of gold from double refractory gold ores. US Patent, no. 8262768 B2, 2012.

26. Fomenko I.V., Pleshkov M.A. Zaytsev P.V., Chugaev L.V., Shneerson Y.M. The use of special additives to inhibit pregrobbing of gold in the process of double refractory concentrates pressure oxidation. Alta 2016 Gold-PM Session. Perth, 2016. pp. 231-241.

27. Brunk K.A., Ramadorai G., Seymour D., Traczyk F.P. Flash chlorinationa new process for treatment of refractory sulphide and carbonceous gold ores. Proceedings of Randol Gold Forum. Golden, CO, Randol International Ltd, 1988. pp. 127-129.
28. Adams M.D., Burger A.M. Characterization and blinding of carbonaceous preg-robbers in gold ores. Minerals Engineering, 1998, no. 11, pp. 919-927.

29. Abruzzese C., Fornari P., Massidda R., Vegliò F., Ubaldini S. Thiosulfate leaching for gold hydrometallurgy. Hydrometallurgy, 1995, no. 39, pp. 265-276.

30. Wan R.Y., Le Vier K.M., Clayston R.B. A hydrometallurgical process for the recovery of precious metals from ores. US Patent, no. 05354359,1994

31. Oktay C., Ersin Y.Y., Haci D. A preliminary study on nitric acid pre-treatment of refractory gold/silver ores. $25^{\text {th }}$ International Mining Congress and Exhibition of Turkey (IMCET). Antalya, 2017. pp. $463-468$.

32. Rusalev R.E., Rogozhnikov D.A., Naboichenko S.S. Nitric acid treatment of Olympiada deposit refractory gold-bearing concentrate. International Russian Conference on Materials Science and Metallurgical Technology. Vladivostok, 2018. pp. 541-546.

33. Anderson C.G. Applications of NSC pressure leaching. Pressure Hydrometallurgy, 2004, vol. 3, pp. 855-886.

34. Ackerman J.B., Anderson C.G., Nordwick S.M., Krys L.E. Hydrometallurgy at the Sunshine metallurgical complex. Proceedings of the Fourth International Symposium on Hydrometallurgy. Litleton, Colorado, SME, 1993. pp. 477-496.

35. Anderson C.G. The application and economics of industrial NSC pressure leaching to copper ores and concentrates. COBRE 2003. Santiago, 2003. pp. 1-15.

36. Shatalov V.V., Kurkov A.V., Nikonov V.I., Boldyrev V.A., Smirnov K.M., Pastukhova I.V., Menshikov Yu.A., Gushchina R.P. Sposob pererabotki upornykh uranovykh soderzhashchikh pirit $i$ blagorodnye metally materialov dlya izvlecheniva urana i polucheniya kontsentrata blagorodnykh metallov [A method of processing refractory uranium containing pyrite and precious metals for the extraction of uranium and the production of a concentrate of precious metals]. Patent RF, no. 2398903 C1, 2009.

37. Smirnov K.M., Raspopov N.A., Shneerson Y.M., Lapin A.Y. Autoclave leaching of molybdenite concentrates with catalytic additives of nitric acid. Russian Metallurgy (Metally), 2009, no. 7, pp. $588-595$.

38. Moreno-Castilla C., Ferro-García M.A., Joly J.P., Bautista-Toledo I., Carrasco-Marín F., Rivera-Utrilla J. Activated carbon surface modifications by nitric acid, hydrogen peroxide, and ammonium peroxydiate treatments. Langmuir, 1995, no. 11, pp. 4386-4392.

39. Díaz X., Snihvrowych M. MAC's with nitric acid pretreatment. Internal report. Utah, University of Utah, 2004. 7 p.

Received 27 June 2021.

Information about the authors

Daniil V. Gordeev, postgraduate student, Saint-Petersburg Mining University.

Georgiy V. Petrov, Dr. Sc., professor, Saint-Petersburg Mining University.

Arthur V. Khasanov, postgraduate student, Saint-Petersburg Mining University.

Olga V. Severinova, master student, Saint-Petersburg Mining University. 